\title{
Studi Kursi Berbahan Kardus
}

\section{Budiono}

Dosen Jurusan Desain Interior, FTSP, Institut Teknologi Sepuluh Nopember, Surabaya, Indonesia

budiono@interior.its.ac.id

\begin{abstract}
ABSTRAK
Kursi berbahan dasar kardus telah banyak didesain dan diproduksi serta akan terus dilakukan upaya riset dan pengembangan. Upaya peningkatan mutu desain dilakukan minimal melalui kajian dasar yaitu kekuatan dan kekakuan, proses produksi/konstruksi, estetika, serta fungsionalitasnya.

Upaya kreatif desain kursi berbahan dasar kardus sangat menarik untuk dilakukan dalam rangka mendukung sektor usaha kecil dan menengah yang sedang tumbuh belakangan ini. Kursi berbahan dasar kardus memiliki beberapa potensi penting diantaranya adalah memanfaatkan material limbah, material mudah didapatkan, material relatif murah serta proses pembuatan/konstruksinya dapat dilakukan relatif mudah dan cepat.

Permasalahan desain kursi kardus yang dicarikan solusinya dalam penelitian ini meliputi kekuatan dan kekakuan, esetika dan semantika bentuk, serta kinerja fungsinya. Dari analisa terhadap produk eksisting dapat dihasilkan katagorisasi produk dari segi struktur dan konstruksinya, serta dari segi estetikanya.

Untuk menjawab permasalahan di atas disusunlah konsep desain kursi kardus. Konsep desain ini diimplementasikan kedalam beberapa alternatif dan varian desain kursi kardus berupa gambar desain dan mock-up/Prototip. Hasil desain tersebut akhirnya diukur untuk menentukan kelayakan jualnya melalui kuesioner pada sejumlah responden.
\end{abstract}

Kata Kunci :kursi, kardus, struktur, estetika.

\section{ABSTRACT}

Cardboard chairs have been recently designed and produced and will continuously be taken an effort to its research and development.Quality improvement is being taken through basic research on several facts, i.e. strength and stability, production and construction, aesthetic and function.

The creative effort of the cardboard chair design is interestingly performed to enhance the small and medium enterprises for the country. The cardboard chairs have several potential aspects such as being waste products consumption, huge material availability, low cost and efficient on production.

Design problems found in the cardboard chairs will be solved through this research which includes the strength and stability, aesthetic and semantic factors, and its performances.Through the cardboard chair design analysis will results category of products based on structure, construction, and aesthetic.

To unfold these design problems a Cardboard Chair Design Concept is being developed. The concept is being implemented to various alternative designs of cardboard chair through Plan Drawing and Prototype. The design result will be analys through respondents to determine wether the products are marketable.

Keywords :chair, cardboard, structure, aesthetic.

\section{PENDAHULUAN}

Kursi kardus memiliki potensi perkembangan yang besar saat ini. Namun demikian, terdapat sejumlah kendala dalam pengembangan alternatif dan varian desainnya. Pengembangan desain tersebut berkaitan dengan sejumlah faktor penting yang kemudian dijadikan variabel dalam penelitian. Variabel tersebut adalah keindahan, kekuatan dan kelayakan jualnya. 
Keunikan dan kelebihan dari kursi kardus adalah terkait dengan material kardus yang mudah diperoleh, relatif murah, ringan, mudah dalam pengerjaannya, serta ada banyak karakter dan branding yang dapat dijadikan objek desain. Perihal penting yang juga perlu diperhatikan adalah adanya alur dan pola gelombang kardus. Bahan Kardus memiliki pola dan alur yang harus diperhatikan untuk membentuk kursi yang kuat.

Harapan akhir dari dikembangkannya penelitian ini adalah dapat diproduksinya kursi kardus secara layak jual. Kelayakan jual tersebut juga dijadikan fokus dalam penelitian ini. Sentra industri kecil dan inkubator diharapkan akan dapat memanfaatkan hasil penelitian ini untuk memaksimalkan penjualannya. Kursi kardus yang unik ini diharapkan akan mampu menjadi salah satu andalan bagi UKM di Jawa Timur.

Masalah yang akan diselesaikan dalam penelitian ini dapat dirumuskan sebagai berikut:

1. Bagaimanakah karakteristik desain kursi kardus yang ada hingga saat ini.

2. Bagaimanakah konsepsi estetik dan struktur dari kursi kardus dengan mengeksplorasi kelebihan dan kekurangan material kardus yang menjadi bahan baku utamanya.

3. Bagaimanakah implementasi dari konsepsi tersebut pada desain kursi kardus yang proses pembuatannya cukup sederhana tapi menghasilkan produk yang estetik, kuat, dan diterima oleh konsumen.

Sedangkan yang ditetapkan sebagai batasan masalah penelitian ini adalah sebagai berikut :

1. Penelitian difokuskan pada variabel estetika, kekuatan, dan kelayakan jualnya.

2. Penelitian tidak dilaksanakan terhadap keilmuan lain selain desain.

3. Penelitian dilaksanakan pada bahan kardus dan tidak dibandingkan dengan material lainnya.

Tujuan dari penelitian ini adalah :

1. Mendapatkan gambaran peta produk kursi kardus yang ada hingga saat ini.

2. Mendapatkan ide/gagasan dalam menyelesaikan masalah desain kursi kardus serta kelayakan jualnya terutama yang terkait dengan kekhasan material kardus dan serta isu lingkungan.

3. Menghasilkan alternatif dan varian desain sebagai implementasi ide di atas.

Sedangkan manfaat yang diharapkan dari penelitian ini adalah :

1. Manfaat bagi UMKM dan Masyarakat

Hasil penelitian ini akan dapat dijadikan masukan yang dapat digunakan dan dikembangkan oleh industri kecil. Varian desain akan memperkaya khasanah produk dan nilai jual kursi kardus sehingga akhirnya bisa membantu meningkatkan pendapatan UMKM dan masyarakat.

2. Manfaat bagi Desainer

Penelitian yang mengukur keberhasilan suatu desain akan selalu menjadi masukan bagi desainer untuk meningkatkan kualitas desainnya. Desainer akan memperoleh masukan minimal dari variabel yang mempengaruhi keindahan dan kekuatan kursi kardus.

3. Manfaat bagi Peneliti

Penelitian ini masih akan terbuka untuk dilanjutkan dengan penelitian berikutnya dalam upaya peningkatan mutu desain kursi kardus, mutu produk kursi kardus, dan peluang bisnisnya.

\section{METODOLOGI}

Metode penelitian dalam mengembangkan karya desain yang termasuk baru ini adalah menggunakan lima tahapan penelitian secara kualitatif dan kuantitatif. Penelitian kualitatif 
digali pada tahapan pencarian ide bentuk hingga perwujudannya, sedangkan kuantitaif dilaksanakan untuk memperoleh kelayakan jual dari varian desain kursi kardus yang ada. Bagan tahapan dalam penelitian ini adalah seperti di bawah ini.

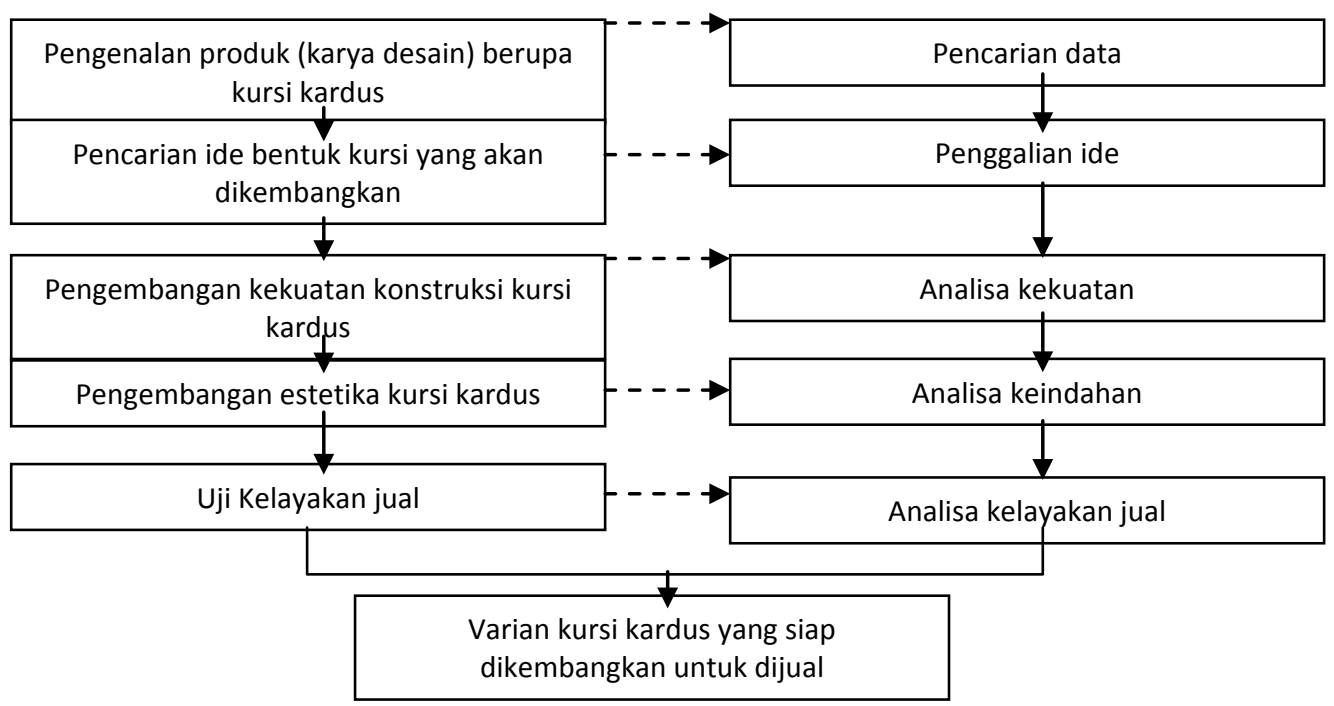

Gambar 1. Tahapan Penelitian Sumber : Konstruksi Penulis

\section{Penggalian Data}

Penggalian data diperoleh dari berbagai masukan. Salah satu data penting yang akan digali adalah dari khalayak umum. Penggalian data ini berada pada tahapan pengenalan karya kursi kardus. Dengan memberikan penekanan (keutamaan) pada pengenalan sifat kardus dan perangkaiannya, maka diharapkan setiap khalayak yang dimintai data tersebut akan mampu mengenali kekuatan dan kelemahan material kardus tersebut.

Proses selanjutnya adalah penggalian ide bentuk. Dalam proses tersebut, penggalian ide bentuk diutamakan pada penemuan berbagai alternatif desainnya. Salah satu bagian dalam alternatif tersebut adalah kemungkinan desain yang berseri (serial desain) dalam satu variasi desainnya.

\section{Proses Analisa Data dan Hasil Analisa}

Analisa dilakukan pada berbagai sisi desain. Analisa yang penting dilakukan adalah analisa:

a. Analisa struktur dan konstruksi

b. Analisa estetika dan semiotika

c. Analisa kelayakan jual dari varian yang didesain

Analisa tersebut dilakukan secara kuantitatif. Proses perhitungan dilaksanakan dengan menggunakan pembobotan (score) dan kemudian di hitung dengan prosesntase. Dalam proses perhitungan tersebut nilai terbesar akan menjadi prioritas untuk menjadi karya yang berhasil dibandingkan karya yang memperoleh nilai prosentase yang lebih sedikit.

\section{Hasil}

Kesimpulan dan akhir dari rangkaian penelitian yang berupa desain kursi kardus yang layak untuk diproduksi karena sudah layak jual. 


\section{PEMBAHASAN}

Dari hasil studi terhadap produk eksisting kursi kardus yang ada saat ini, maka dapat dibuat pengelompokan tipe kardus. Pembagian tipe ini terutama berdasarkan segi struktur (bagaimana kursi bisa berdiri) dan konstruksi (bagaimana kursi bisa dibuat/dirakit). Beberapa tipe kursi kardus (karton bergelombang) adalah sebagai berikut:

Tabel 1. Tipologi Kursi Kardus berdasarkan Struktur dan Konstruksinya.

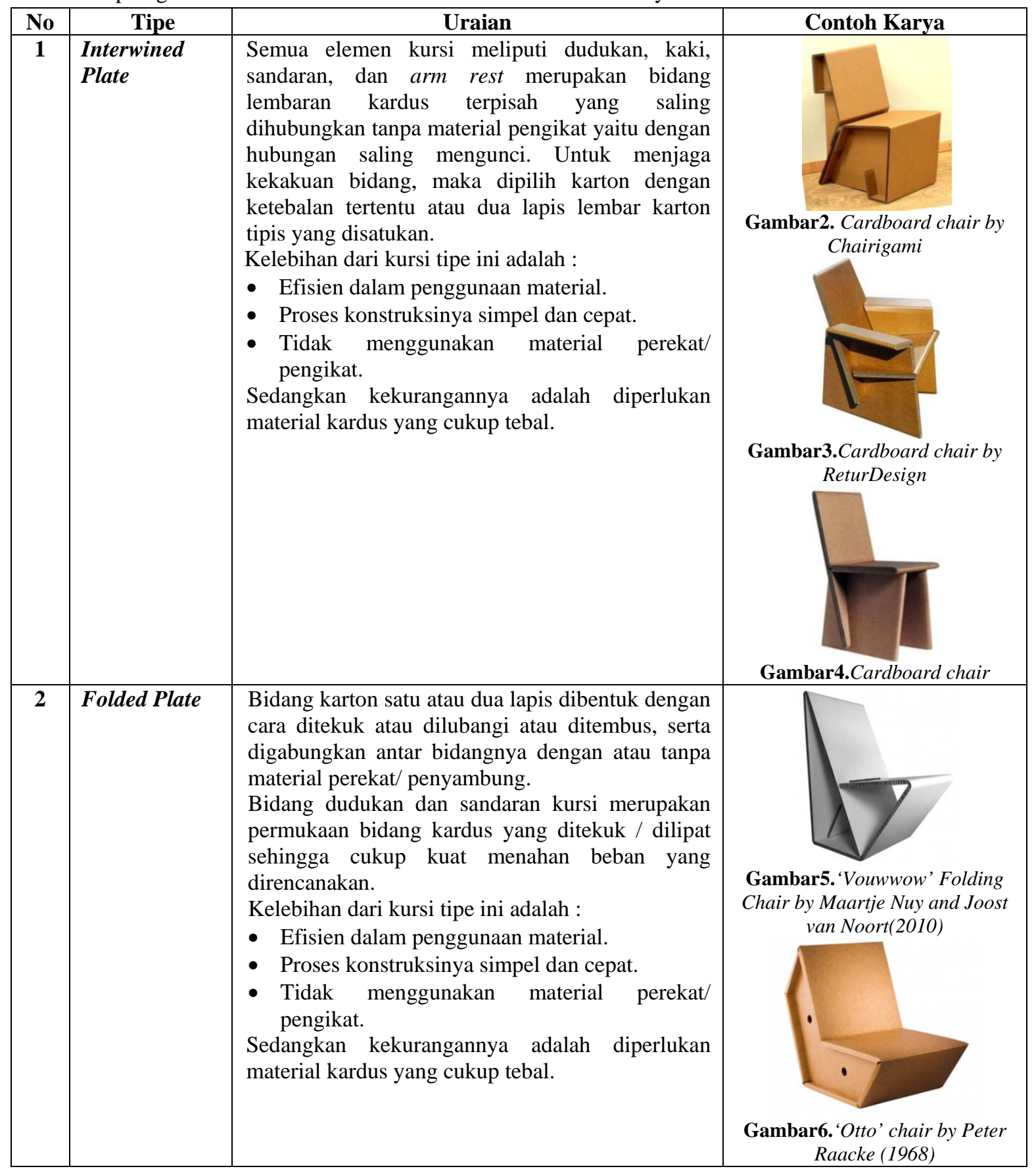




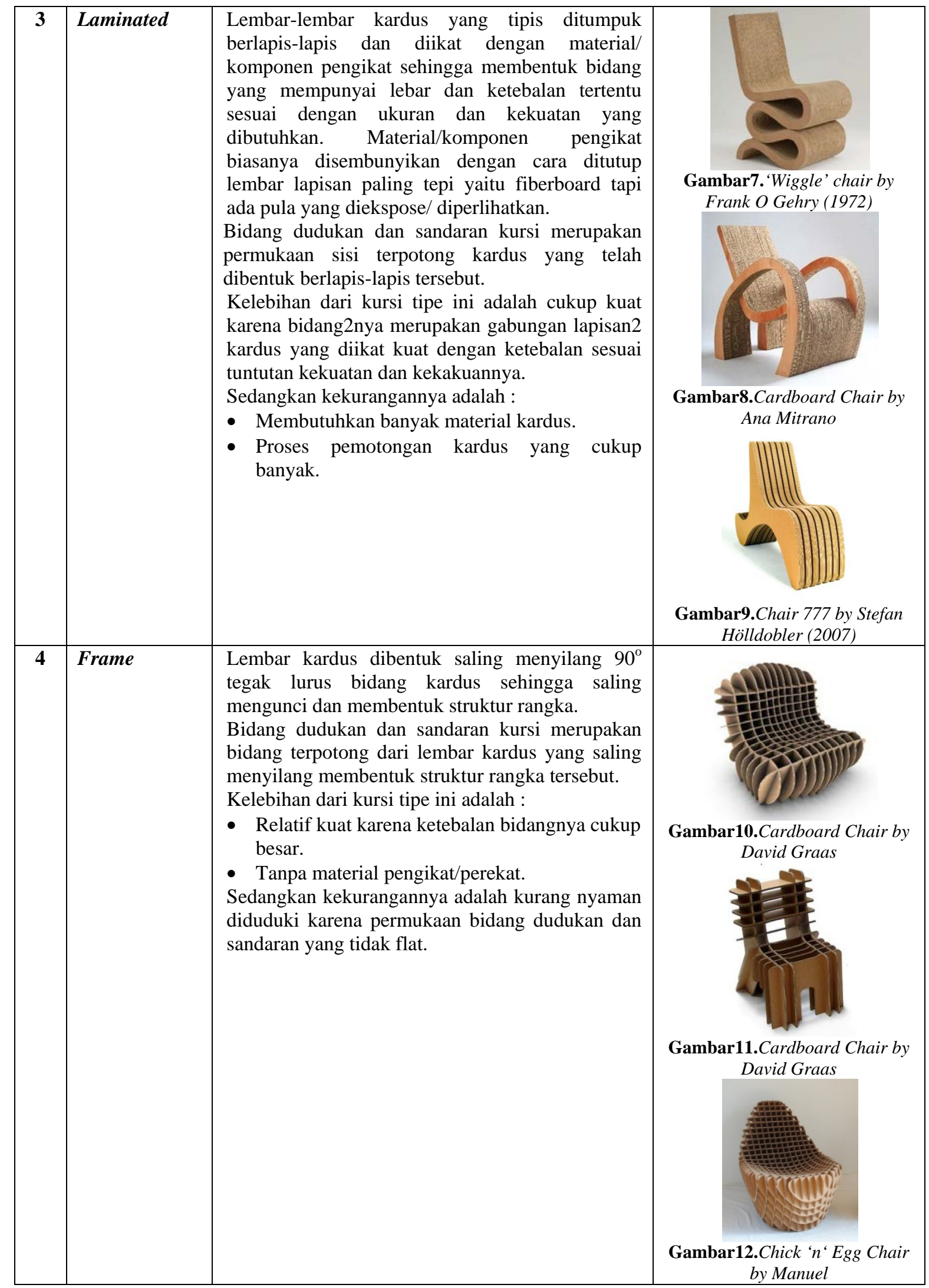




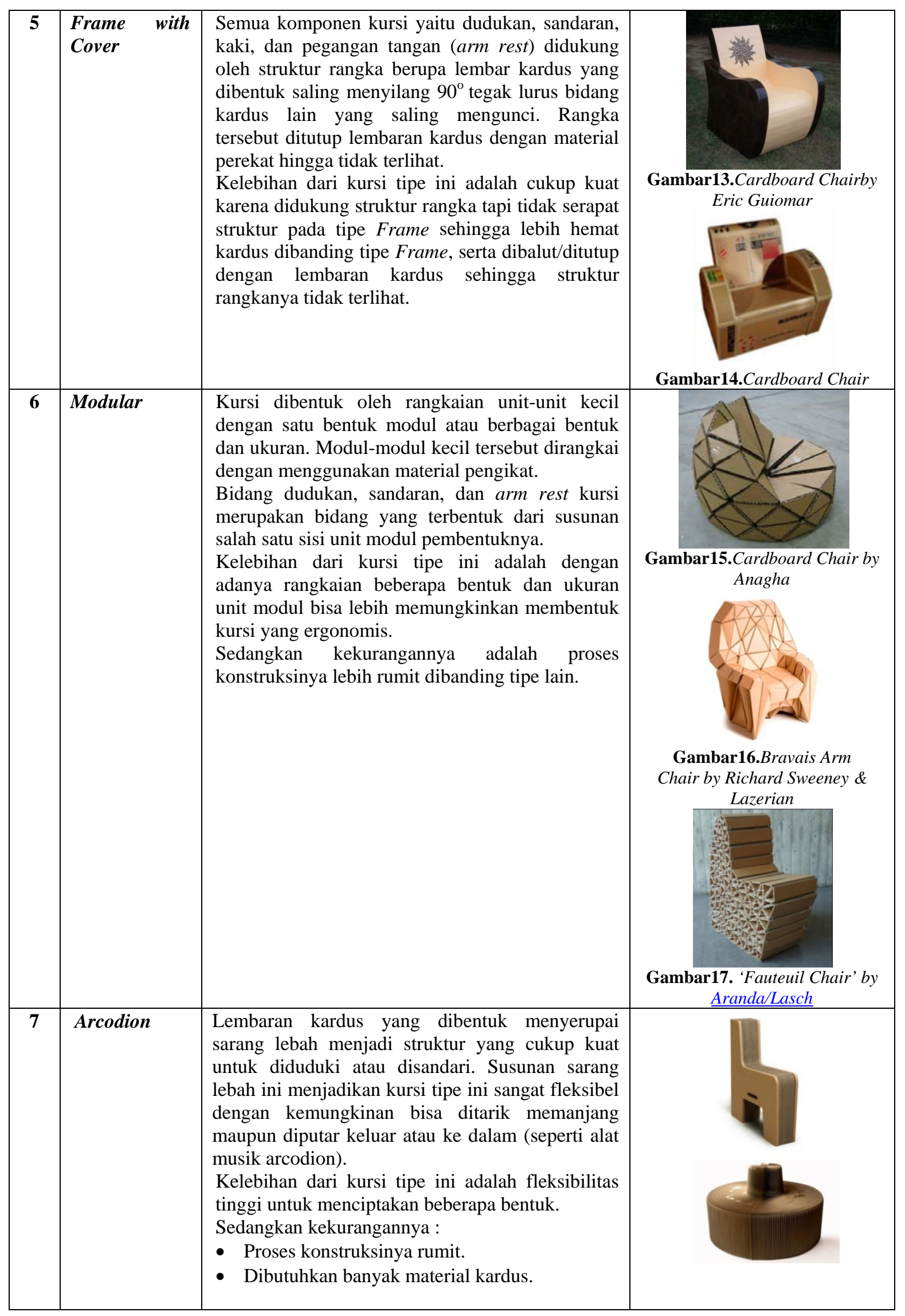




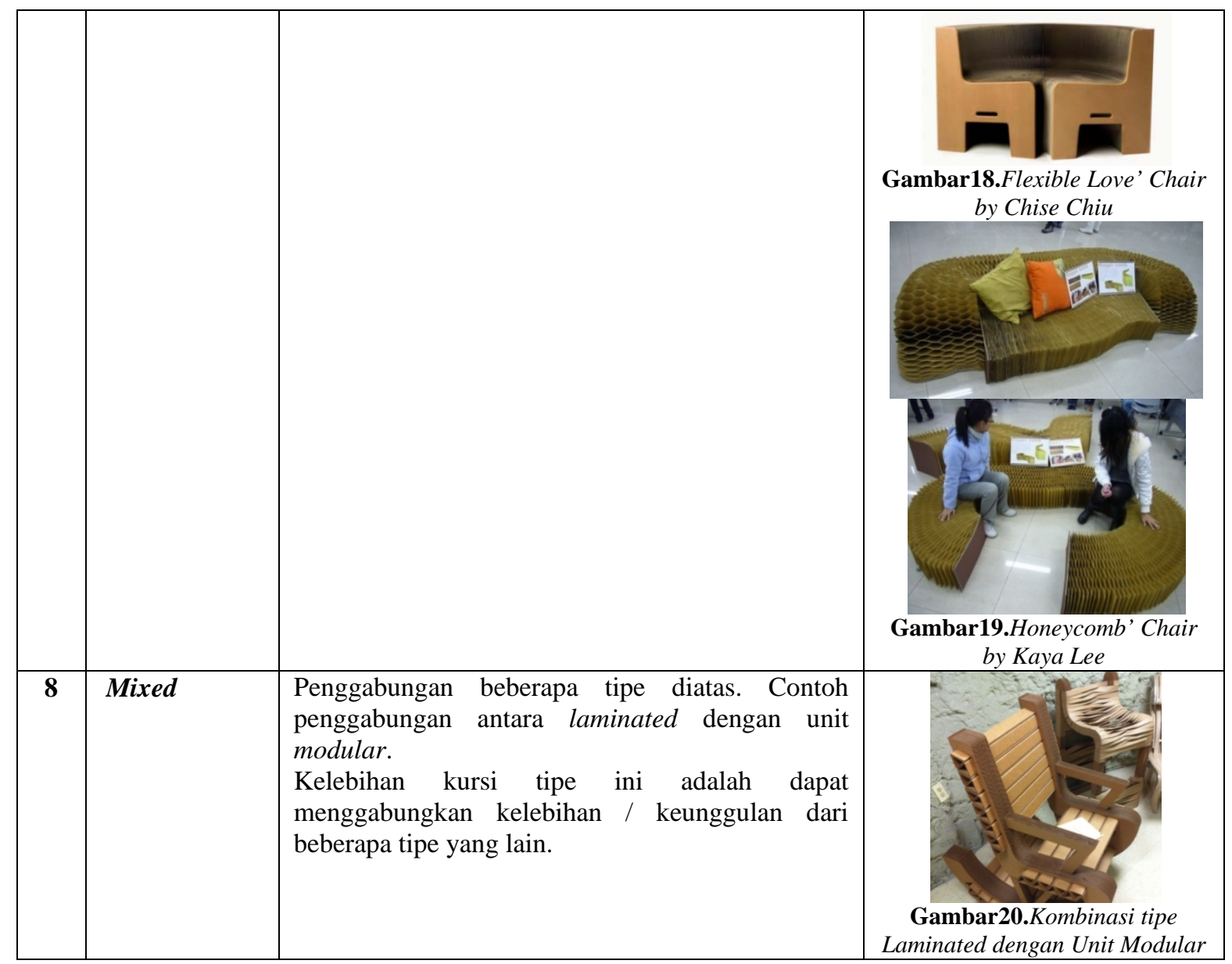

\section{Permasalahan Desain Kursi Kardus}

Dari hasil analisa pustaka dan eksisting dapat diketahui bahwa permasalahan desain kursi kardus adalah sebagai berikut :

a. Kekuatan dan kekakuan kursi untuk menahan beban sesuai fungsi kursi.

b. Kesederhanaan pembuatan dan perakitan kursi kardus.

c. Kenyamanan (antropometris) ketika duduk sesuai fungsi kursi.

d. Efisiensi penggunaan bahan baku kardus.

e. Kesan estetika visual kursi kardus.

f. Kesan semiotika dan branding kursi kardus.

\section{Konsep Desain Kursi Kardus}

Ide/gagasan guna menjawab masalah atau konsep desain kursi kardus dapat dirumuskan sebagai berikut :
a. Konsep struktur dan konstruksi.
b. Konsep kenyamanan (antropometris).
c. Konsep efisiensi penggunaan bahan baku.
d. Konsep estetika visual.
e. Konsep semiotika dan branding.

Semua konsep di atas perlu dipertimbangkan dalam proses desain kursi kardus, namun pada penelitian ini lebih difokuskan pada konsep estetika dan branding. Sebagaimana desain kursi berbahan selain kardus, estetika visual desain kursi kardus 
dihadirkan melalui pemilihan komposisi elemen-elemen desainnya: material, warna atau finishing, ukuran kursi atau unit-unit terkecilnya, serta langgam desainnya. Komposisi yang baik akan membuat terciptanya kesatuan bentuk sehingga kesan estetik akan tercapai.

Kecenderungan orang untuk memilih sebuah desain kursi selain karena aspek estetika yang dihadirkan melalui bentuk kursi juga karena aspek fungsi (kegunaan). Pertimbangan pada bentuk dan fungsi ini menuntut adanya beberapa penyelesaian desain (design treatment) kursi kardus yang dapat dikatagorikan sebagai berikut :

a. Bentuk Fix atau Fleksibel :

1) Bentuk kursi Fix

2) Fleksibel posisi berdiri kursi

3) Fleksibel seperti Arcodion

b. Struktur kursi di ekspos/ditampakkan atau tidak diekspos :

1) Struktur kursi diekspos

2) Struktur kursi tidak diekspos/ditutupi

c. Finishing kursi

1) Tidak difinish

2) Difinish dengan cat/material pewarna

3) Dilapisi dengan stiker

Dalam penerapannya pada sebuah desain kursi kardus, maka penyelesaian desain (design treatment) tersebut mengalami kombinasi dengan beberapa kemungkinan alternatif sebagaimana yang digambarkan pada tabel berikut :

Tabel 2. Alternatif Kombinasi 'Aesthetical Treatment' pada Desain Kursi Kardus.

\begin{tabular}{|c|c|c|c|c|c|c|c|c|c|}
\hline \multirow[b]{2}{*}{ 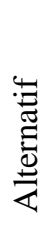 } & \multirow[b]{2}{*}{ Contoh Desain } & \multicolumn{8}{|c|}{ Penyelesaian Estetika (Aesthetical Treatment) } \\
\hline & & 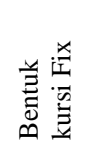 & 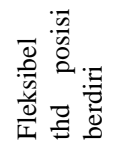 & 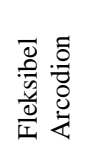 & 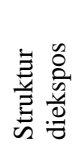 & 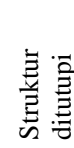 & 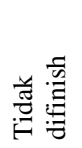 & 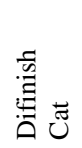 & 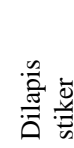 \\
\hline 1 & & $\checkmark$ & & & $\checkmark$ & & $\checkmark$ & & \\
\hline 2 & & $\checkmark$ & & & $\checkmark$ & & & $\checkmark$ & \\
\hline 3 & & $\checkmark$ & & & $\checkmark$ & & & & $\checkmark$ \\
\hline 4 & & $\checkmark$ & & & & $\checkmark$ & $\checkmark$ & & \\
\hline
\end{tabular}




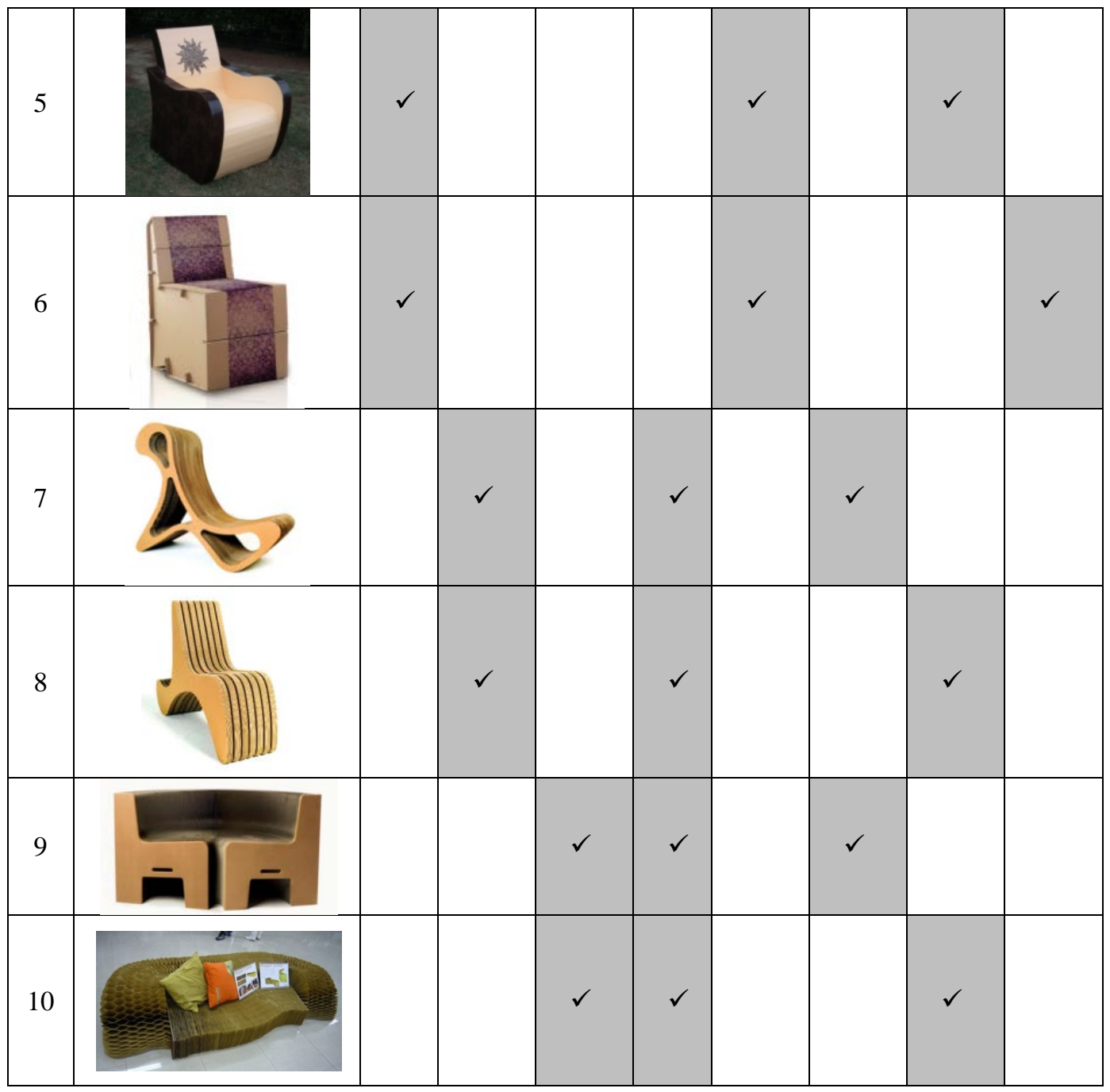

Selain konsep Estetika di atas diajukan pula konsep branding serta penyampaian pesan melalui tanda pada produk kursi kardus yang dilakukan dengan mengambil stilasi bentuk dan warna dari benda/produk rujukan. Contohnya adalah seperti digambarkan pada tabel berikut :

Tabel 3. Contoh Stilasi Bentuk dan Warna Kursi Kardus dari Benda Rujukan.

\begin{tabular}{|l|c|c|c|}
\hline No & Benda Rujukan & Bentuk Hasil Stilasi \\
\hline 1 & & &
\end{tabular}




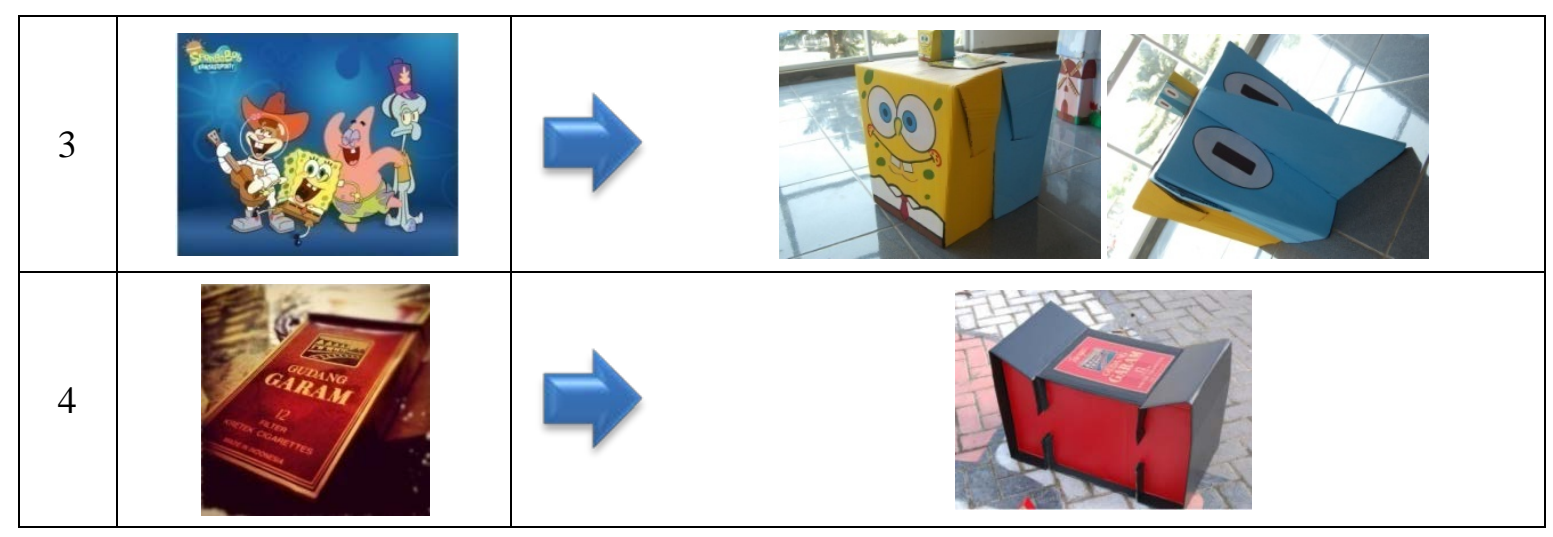

\section{KESIMPULAN}

Dari hasil penelitian ini dapat ditarik beberapa kesimpulan sebagai berikut :

1. Produk kursi kardus sudah dikenal sejak hampir 40 tahun yang lalu, dan sudah mengalami pasang surut popularitas hingga pada era globalisasi ini menjadi populer lagi seiring isu lingkungan global. Bahan baku dari kardus/ karton bergelombang yang bisa diambil dari bahan daur ulang yang sarat dengan pesan ramah lingkungan, proses pembuatan yang sederhana, mudah, cepat dan murah menjadikan produk ini punya potensi besar bersaing di masa kini dan mendatang.

2. Inovasi-inovasi desain dan produksi kursi kardus berpeluang dikembangkan baik dari segi pengolahan/penanganan bahan baku utama (kardus), bahan kombinasi (selain kardus), bahasa desain (estetika dan semantika produk), serta teknologi produksinya.

3. Penelitian ini masih perlu dilanjutkan dengan penelitian berikutnya antara lain yang terkait dengan optimalisasi penggunaan bahan dan struktur untuk produk furnitur berupa kursi maupun furnishing dan elemen dekoratif lainnya.

\section{SARAN}

Beberapa yang perlu ditindak lanjuti untuk mengembangkan potensi kursi kardus sebagai produk UMKM furnitur adalah :

1. Para pihak yang terkait dengan peningkatan kualitas produk furnitur antara lain institusi pendidikan, industri furnitur, dan pemerintah dapat lebih meningkatkan upayanya untuk mengkaji dan mengembangkan kualitas desain dan produk furnitur berbahan kardus antara lain dengan diadakannya workshop kursi kardus, sayembara kursi kardus, penghargaan karya furnitur kardus terbaik, serta kegiatan utuk meningkatkan apresiasi masyarakat terhadap produk kursi/furnitur kardus.

2. Menumbuhkan kerjasama antar industri furnitur kardus, antara institusi pendidikan, industri dan pemerintah dalam rencana dan kegiatan pendampingan ketrampilan, pemasaran, promosi, dan pendanaan.

\section{DAFTAR PUSTAKA}

[1] Sembach-Leuthauser-Gossel, 1991, Twentieth-Century Furniture Design. Taschen, Koln.

[2] "Cardboard Furniture." Wikipedia. Wikimedia Foundation, Inc, http://en.wikipedia.org/wiki/Cardboard_furniture. Diakses tgl 10 Oktober 2013.

[3] "Cardboard Furniture Store." Cardboard Furniture Company. WordPress,. http://www.cardboardfurniturestore.com. Diakses tgl 11 Oktober 2013.

[4] Design Museum, Fifty Chairs that Changed the World, Conran Octopus. 